DOI: $10.1515 /$ travmu-2015-0007

Faunistic Note

\title{
THE FIRST REPORT OF STEPPE POLECAT (MUSTELA EVERSMANII LESSON, 1827) DOCUMENTED IN MOLDOVA (ROMANIA)
}

\author{
CONSTANTIN ION, LOREDANA DONISAN, DIANA-ELENA ȘUȘNEA
}

\begin{abstract}
The Steppe Polecat lives in Europe, in a variety of relatively dry habitats. Its distribution is not sufficiently known in Romania. On the $22^{\text {nd }}$ of February, 2014 we found a dead specimen of Steppe Polecat, north from Bucecea city. This is the first report of Steppe Polecat for North-East Romania.
\end{abstract}

Résumé. Le putois des steppes vit en Europe dans une variété d'habitats relativement secs. Sa distribution n'est pas suffisamment connue, en particulier en Roumanie. Le 22 Février 2014, nous avons trouvé au nord de la ville Bucecea un spécimen mort de putois des steppes. Ainsi, on signale cette espèce pour la première fois du Nord-Est de la Roumanie.

Key words: Steppe Polecat, distribution, Moldova Region, Siret Valley.

The Steppe Polecat occurs from Central and Eastern Europe in the West, through Southern Russia and Central Asia to South Siberia in the East. There is a severe lack of knowledge about the Steppe Polecat distribution in the southeastern part of its areal (Schreiber et al., 1989).

According to Mitchell-Jones et al. (1999), in Europe, this species is represented by two major populations that are separated by the Carpathians.

The Steppe Polecat lives in Europe in a variety of relatively dry habitats. Its distribution coincides often with populations of ground squirrels, hamsters and water voles. Its presence was confirmed in Central and Eastern Europe, but not in NorthEast Romania, until now.

In Romania, Steppe Polecat is present especially in Dobrogea. It is characteristic for North Dobrogea, being reported by the local people at Baia, Cerna and Greci (Murariu, 2006). The species was also reported in Tătaru Islet and Cape Doloșman (Oțel et al., 2000). There is some information on its presence in three sites in Muntenia and Oltenia and one in southern Romania (Almășan, 1962; Barbu, 1971). Recent data showed that the Steppe Polecat has a wider distribution. Hegyeli (2009) provided the first data on the occurrence of the species in western Romania. The species was seen in eastern Romania (Moldova) and southern Muntenia (Romania) (Hegyeli, unpublished data).

There are lots of steppe habitats in Eastern Romania (Moldova Region) proper for the Steppe Polecat.

The total polecats population of Romania is estimated at 1.000 individuals (Murariu, 2005). The species is listed as vulnerable in the Red Data Book of Romanian Vertebrates and its hunting is prohibited according to the Romanian hunting legislation.

The Steppe Polecat lives in a variety of relatively dry habitats, including grasslands, meadows, cultivate fields. It is a nocturnal animal (Šálek et al., 2013).

This species is endangered by persecution in the western parts of its range; in Russia it is commonly hunted for fur, and in China it is affected by habitat loss 
(Mitchell-Jones et al., 1999). The Steppe Polecat is hunted also for its pelts. In Moldova, it is affected by overgrazing, persecution and car accidents.

The individual we found (on the $22^{\text {nd }}$ February, 2014) was lying near the Site of Community Importance Dorohoi - Şaua Bucecei, on Siret Valley, North from Bucecea town, where the habitat type is represented by wet meadows and tall herb communities. Here, there are some patches with steppe vegetation with Taraxaco serotinae - Festucetum valesiacae, Artemisio austriacae - Poëtum bulbosae and Taraxaco serotinae - Botriochloetum ischaemi. Farmlands and sugar beet crops are also common in Siret Valley (Ion et al., 2011).

The Steppe Polecat found has a thin body, pointed and white snout, small and rounded ears with short legs and a thick neck. Its coat is dense, with contour brush back and its legs are yellow colored, with brown hind legs. Its tail is thick, yellowwhitish, with a black distal half (Fig. 1).

\section{ACKNOWLEDGEMENTS}

We thank Diana Moscaliuc for her help in the field. We are grateful to Mr. Kiss Botond and Mr. Ciprian Mânzu for their consultancy.

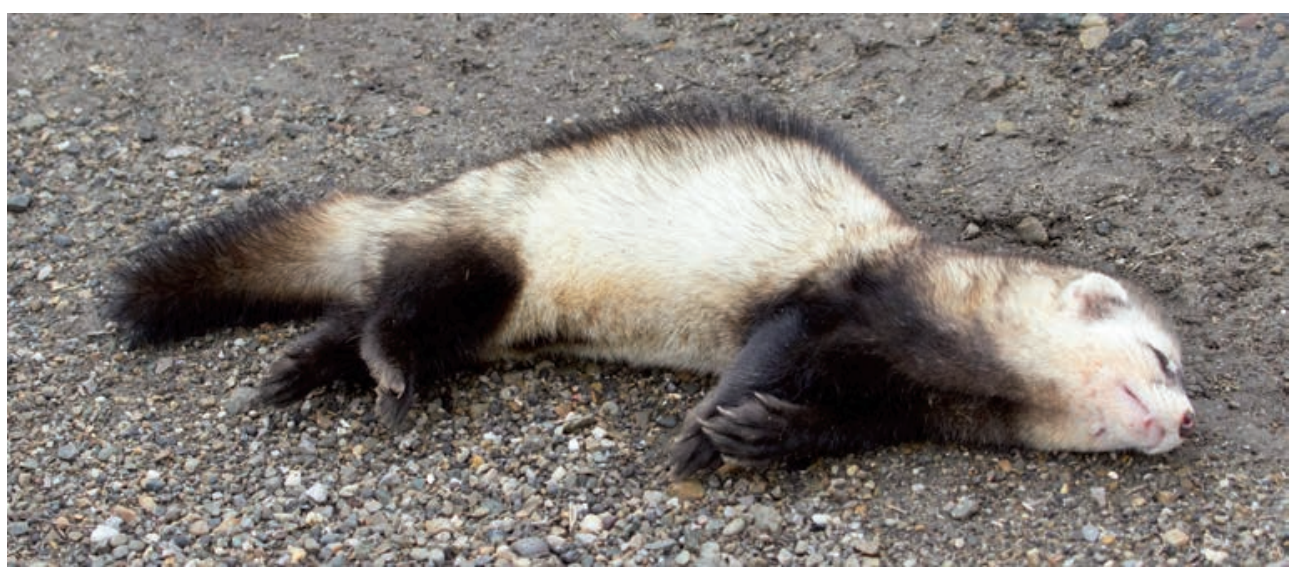

Fig. 1. The Steppe Polecat (Mustela eversmanii) specimen found at Bucecea

\section{PRIMA SEMNALARE DOCUMENTATĂ A DIHORULUI DE STEPĂ (MUSTELA EVERSMANII LESSON, 1827) ÎN MOLDOVA (ROMANIA)}

\section{REZUMAT}

Dihorul de stepă trăieşte în Europa, în habitate cu vegetaţie xerofilă. El este prezent în acele zone cu populaţii de popândăi, hârciogi şi şobolani de apă. Dihorul de stepă este răspândit din Centrul şi Estul Europei, în vest, până în sudul Rusiei, Asia Centrală şi sudul Siberiei, în est. În România, este prezent în special în Dobrogea. De asemenea, este răspândit în Muntenia, Oltenia şi vestul României. În Moldova nu au fost semnalări certe, publicate. Pe 22 februarie 2014, am găsit un specimen mort de dihor de stepă (Mustela eversmanii), la nord de oraşul Bucecea, pe Valea Siretului, într-o zonă unde există o pajişte de stepă. Este prima semnalare de acest fel din nord-estul României. 


\section{LITERATURE CITED}

ALMĂȘAN, H., 1962 - Observațiuni asupra epocilor de vînătoare. Vînătorul și pescarul 15(2): 35. (in Romanian)

BARBU, P., 1971 - Contributions a la connaissance de la distribution du putois de steppe Mustela (Putorius) eversmanii Lesson, 1827 en Roumanie. Analele Universității București 20: 9-11.

ION, C., C. STOLERIU, E. BALTAG, C. MÂNZU, A. URSU, A. IGNAT, 2011 - Păsările şi habitatele din zonele umede ale Moldovei, Editura Universităţii „Alexandru Ioan Cuza” Iaşi: 56-57. (in Romanian)

MITCHELL-JONES, A. J., G. AMORI, W. BOGDANOWICZ, B. KRYŠTUFEK, P. J. H. REIJNDERS, F. SPITZENBERGER, M. STUBBE, J. B. M. THISSEN, V. VOHRALIK, J. ZIMA, 1999 - The Atlas of European Mammals. Academic Press, London, UK: 330-332.

MURARIU, D. in BOTNARIUC, N., TATOLE, V., 2005 - Cartea Roșie a Vertebratelor din România. Muzeul Național de Istorie Naturală „Gr. Antipa”, Bucureștí: 68. (in Romanian)

MURARIU, D., 2006 - Mammal Ecology and distribution from North Dobrogea (Romania). Travaux du Muséum National d'Histoire Naturelle „Grigore Antipa”, 49: 387-399.

OȚEL, V., V. CIOCÂRLAN, A. FEDORCHENKO, J. B. KISS, D. MURARIU, E. NIȚU, 2000 - The Red List of Plant and Animal species from the Danube Delta Biosphere Reserve, 128-129.

ŠÁLEK, M., N. SPASSOV, M. ANDĚRA, K. ENZINGER, B. OTTLECZ, Z. HEGYELI, 2013 Population status, habitat associations, and distribution of the steppe polecat Mustela eversmanii in Europe, Acta Theriologica, 58: 233-244.

SCHREIBER, A., R. WIRTH, M. RIFFEL, H. van ROMPAEY, 1989 - Weasels, civets, mongooses, and their relatives. An Action Plan for the conservation of mustelids and viverrids. IUCN, Gland, Switzerland, 100 pp.

Received: September 23, 2014

Accepted: October 2, 2015
"Alexandru Ioan Cuza" University, Faculty of Biology Carol I Blvd. 20A, 700505 Iași, Romania

e-mails: costin_zoo@yahoo.com donisan.loredana@yahoo.com diana_shush@yahoo.com 